\title{
Socio-ecological System Functioning Under Changing Climate: An Impact Assessment
}

\author{
S Srikantaswamy ${ }^{1 *}$, M. R. Abhilash ${ }^{1}$, Appaji Gowda ${ }^{2}$, Alaa Swamy ${ }^{1}$ and K Jagadish ${ }^{1}$ \\ ${ }^{1}$ Department of Studies in Environmental Science, University of Mysore, India \\ ${ }^{2}$ Department of Anthropology, Karnataka State Open University, India
}

Submission: February 10, 2021; Published: March 02, 2021

*Corresponding author: S Srikantaswamy, University of Mysore, Manasagangotri, Mysore 570006, India

Abstract

This study aims to explore the impact of climate change on sustainable development in Mysore district using recent survey-based data. The study was conducted based on the perception of the respondents of 7 taluks in Mysore District. A total of 384 respondents were surveyed following stratified random sampling. It was determined based on the Krejcie \& Morgan's [1] sample size calculation, based on $p=0.05$ where the probability of committing type I error is less than $5 \%$ or $\mathrm{p}<0.05$, the results identified that the impact of climate change perceived by respondents included ten major components viz. crop nature, soil condition, water crisis, pest incidence, disease menace, agro climatic status, economic fluctuations, social situation, health statusque and psychological grief. Each major component has been studied with subcomponents. Each major and sub components were subjected to standardization procedure. After the standardization process, responses were obtained from the respondents on three-point continuum scale. (Fully perceived, partially perceived, not perceived) and with the scores of 3, 2 and 1 respectively. Mean scores were computed for each of the components and average mean scores were obtained. The index range for various subcomponents, crop nature (0.702), soil condition (0.689), water crisis (0.706), pest incidence (0.646), disease menace (0.625), agro climatic status (0.755), economic fluctuations (0.920), social situation (0.597), health statuesque (0.467) and psychological grief (0.614).

Keywords: Climate change; Sustainable development; Mysore district

\section{Introduction}

Climate change has been predicted to exert severe impacts on agriculture, economy and livelihoods in developing countries. India highly vulnerable to the problem because a large portion of its population depends on climate sensitive sectors like agriculture and forestry for livelihood [2-5]. By adversely affecting freshwater availability and quality, biodiversity and desertification, climate change tends to disproportionately affect the poorest in the society, exacerbating inequities in access to food, water and health. The capacity to adapt is a function of access to wealth, scientific and technical knowledge, information, skills, infrastructure, institutions and equity and therefore varies among regions and socio-economic groups [6]. Climate change therefore is intrinsically linked to other environmental issues and to the challenge of sustainable development [4].

India is considered to be especially vulnerable to the impacts of climate change due to the present of an extraordinary variety of climatic regions, ranging from tropical in the south to temperate and alpine in the Himalayan north, where elevated regions receive sustained winter snowfall [7-9]. The northern part of the country has a continental climate with severe summer conditions that alternates with cold winters when temperatures plunge to freezing point. In contrast are the coastal regions of the country, where the warmth is unvarying and the rains are frequent. Climate change is likely to affect all the natural ecosystems as well as socioeconomic systems as shown by the National Communications Report of India to the UNFCCC [10]. Various studies have indicated a probability of 10 to 40 per cent loss in crop production in the country due to the anticipated rise in temperature by 2080 [7].

In India, climate change is leading to additional stress on ecological and socio-economic systems that are already facing tremendous pressures due to rapid urbanization, industrialization and economic development [11]. India is at a high risk because of its huge and growing population, a $7500-\mathrm{km}$ long densely populated and low-lying coastline and an economy that is 
closely tied to its natural resource base, India is considered to be especially vulnerable to the impacts of climate change. Like most other developing countries, people in India are dependent to a large extent on its natural resources for livelihood and economy. For example, more than $56 \%$ of workers are engaged in agriculture and allied sectors, while many others earn their living in coastal areas through tourism or fishing. Any adverse impacts on these natural resources will have repercussion on the nation's livelihood security and economy and widen the gap between the rich and the poor [12]. Most of India's poorest people live in rural areas and are almost totally reliant on natural resources for their food, shelter and incomes $[13,14]$. In fact, the poor are already experiencing the impacts of climate change, with few resources to cope up with. Diminishing water resources, and frequent natural disasters are some of such problems, apart from the other existing problems which will be further aggravated by climate change. The problem is that nearly all the alleged negative consequences of climate change are in fact problems that we face today. Future changes in climate may or may not make these problems worse, but the fact remains that unless they are addressed directly, they will continue to remain problems, regardless of attempts to limit human impacts on the climate [15]. This study aims to explore the perceived impact of climate change on sustainable development in Mysore district from the respondent's perspectives.

\section{Materials and Method}

\section{Study area}

The study was conducted in seven taluks (Division) of Mysore District, India (Figure 1). Mysore district is situated in the south of the Karnataka state between $11^{\circ} 60^{\prime \prime}$ to $21^{\circ} 17^{\prime \prime}$ North latitude and $75^{\circ} 19^{\prime \prime}$ to $77^{\circ} 77^{\prime \prime}$ East longitude. The district covers a total geographical area of $6307 \mathrm{~km}^{2}$, which 3.57 per cent of the state's total geographical area. It is bounded by Mandya district to the northeast, Chamarajanagara district to the southeast, Kerala state to the south, Kodagu district to the west, and Hassan district to the north. Mysore city is the headquarters of the district.

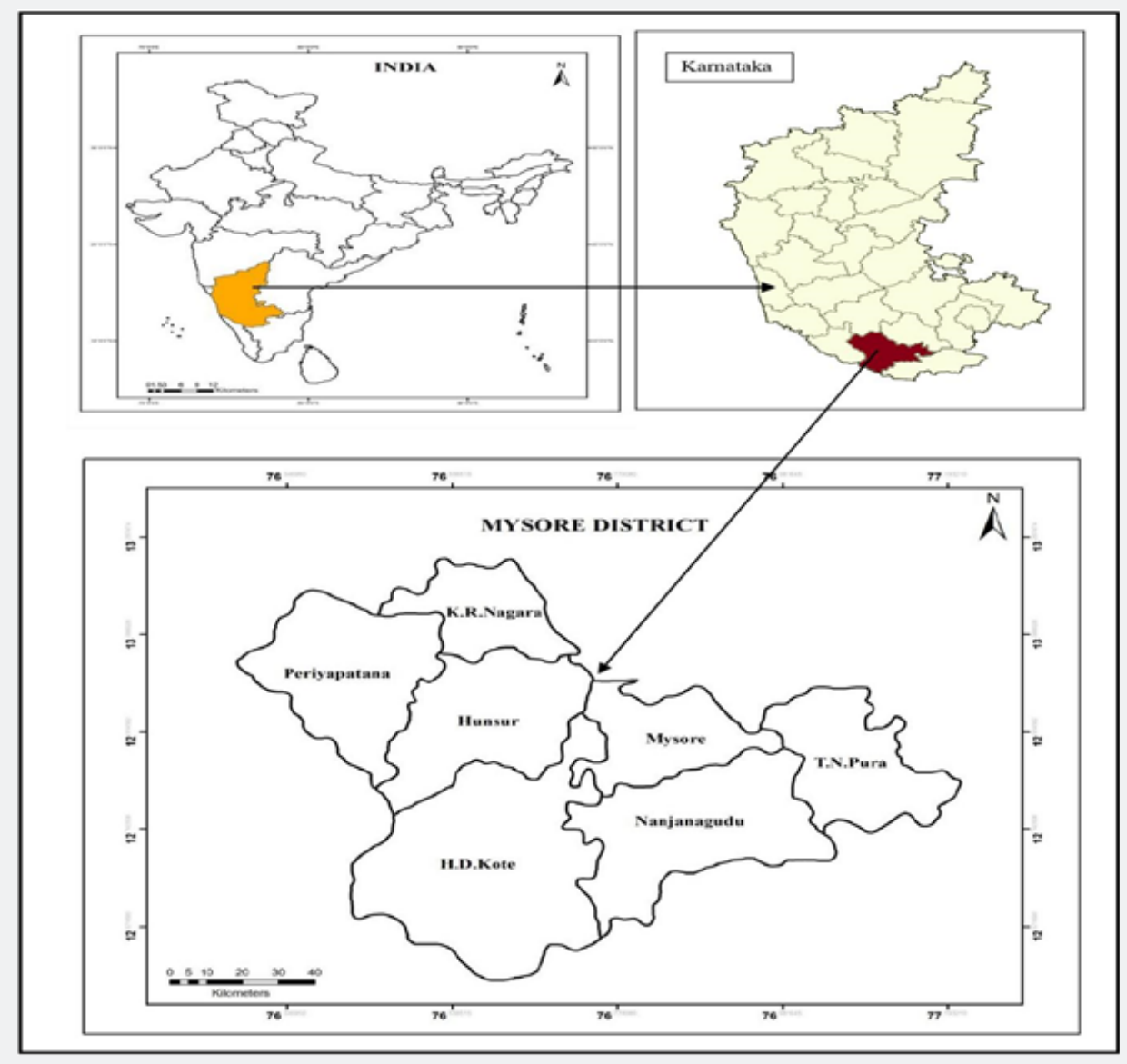

Figure 1: Location of Mysore District in the map of India, indicating the taluks studied.

\section{Methodology and data analysis}

The sample size representative of the farmers in this study is 384. It was determined based on the Krejcie and Morgan's [1] sample size calculation, based on $\mathrm{p}=0.05$ where the probability of committing type I error is less than $5 \%$ or $\mathrm{p}<0.05$. 
The calculated total sample was 384 respondents, and further calculations were undertaken to determine the sample size that needed to be taken from each taluk as shown in Table 1. The criteria followed in the selection of respondents is the head of householders who are working as a Cultivators or Agricultural labourers distributed across all parts of the taluk - North, South,
East and West. The data were collected by using a well-structured and pre-tested interview schedule. The collected data were tabulated and analyzed by using suitable statistical tools (SPSS 22 ), and the salient findings of the study are summarized as follows in the results section.

Table 1: Calculated sample of No. of respondents in Mysore District.

\begin{tabular}{|c|c|c|c|c|c|}
\hline Taluks & $\begin{array}{l}\text { Total Rural } \\
\text { Population }\end{array}$ & Cultivators & $\begin{array}{l}\text { Agricultural La- } \\
\text { bourers }\end{array}$ & Cultivators and Agricultural Labourers & No. of Respondents \\
\hline H. D. Kote & 237,968 & 63,815 & 43,709 & $\begin{array}{l}107524 \\
\mathbf{( 1 6 . 5 9 )}\end{array}$ & 64 \\
\hline Hunsur & 232,098 & 77,588 & 32,616 & $\begin{array}{l}110204 \\
\mathbf{( 1 7 . 0 0 )}\end{array}$ & 65 \\
\hline $\begin{array}{l}\text { K. R. } \\
\text { Nagara }\end{array}$ & 216,852 & 59,799 & 29,281 & $\begin{array}{l}89080 \\
\mathbf{( 1 3 . 7 4 )}\end{array}$ & 53 \\
\hline Mysore & 267,541 & 42,156 & 20,474 & $\begin{array}{l}62630 \\
(\mathbf{9 . 6 6 )}\end{array}$ & 38 \\
\hline Nanjangud & 334,324 & 53,008 & 60,868 & $\begin{array}{l}113876 \\
\mathbf{( 1 7 . 5 6 )}\end{array}$ & 67 \\
\hline $\begin{array}{l}\text { Periyapa- } \\
\text { tna }\end{array}$ & 226,391 & 64,719 & 18,597 & $\begin{array}{c}83316 \\
\mathbf{( 1 2 . 8 5 )}\end{array}$ & 49 \\
\hline $\begin{array}{l}\text { T. Narasi- } \\
\text { pura }\end{array}$ & 240,540 & 36,872 & 44,817 & $\begin{array}{c}81689 \\
\mathbf{( 1 2 . 6 0 )}\end{array}$ & 48 \\
\hline Total & $1,755,714$ & 397,957 & 250,362 & 648,319 & 384 \\
\hline
\end{tabular}

Source: District at a Glance 2016-17. and calculated values from the official data.

\section{Identification and selection of major components and sub-components for assessment of perceived impact of climate change}

Fifteen major components were identified for the assessment of perceived impact index of climate change. According to the assessment of the components and subcomponents, we specified whether each of the identified indicators was felt relevant and suitable for inclusion to assess the perceived impact of climate change. The responses were scored on a three-point continuum viz., 'most relevant', 'relevant' and 'least relevant', and scored as 2 , 1 and 0 , respectively. then the responses were analyzed and the relevancy weightage (RW) of $\mathbf{i}^{\text {th }}$ indicator (RWi) was worked out by using the following formula.

Relevancy weightage $(R W)=\frac{\text { Most } \operatorname{Re} \text { levant } X 2+\text { Relevant } X 1+\text { Not } \operatorname{Re} \text { levant } X 0}{\text { Maximum Possible Score }}$

Considering the relevancy weightage scores, the components were screened. Accordingly, components having relevancy weightage score ranging more than 0.75 alone were considered. Using this process, ten components were selected (Table 2).
Table 2: List of selected perceived impact indicators of climate change with their relevancy weightage.

\begin{tabular}{|c|c|c|}
\hline S.No & Indicators & Relevancy Weightage \\
\hline 1 & Crop nature & 0.9 \\
\hline 2 & Soil condition & 0.88 \\
\hline 3 & Water crisis & 0.87 \\
\hline 4 & Pest incidence & 0.89 \\
\hline 5 & Disease menace & 0.88 \\
\hline 6 & Agro climatic status & 0.9 \\
\hline 7 & Economic fluctuations & 0.86 \\
\hline 8 & Social situation & 0.85 \\
\hline 9 & Health statuesque & 0.86 \\
\hline 10 & Psychological grief & 0.79 \\
\hline
\end{tabular}

The study aimed at assessing the perceived impact of climate change on sustainable development amongst the respondents. It was essential to include the identified major components (Table 3 ) to reflect the wholesome perceived impact of climate change so as to construct the index for this purpose. 


\section{International Journal of Environmental Sciences \& Natural Resources}

Table 3: List of the components and sub-components to assess the perceived impact of climate change.

\begin{tabular}{|c|c|}
\hline S.No. & Components and Sub-components \\
\hline \multirow[t]{5}{*}{1} & Crop nature \\
\hline & Changes in cropping system \\
\hline & Changes in harvesting time \\
\hline & Changes in crop growing season \\
\hline & Crop destruction \\
\hline \multirow[t]{6}{*}{2} & Soil condition \\
\hline & Decreased soil water holding capacity \\
\hline & Increased soil salinity \\
\hline & Reduced soil nutrient content \\
\hline & Soil erosion \\
\hline & Accumulation of trash and debris \\
\hline \multirow[t]{5}{*}{3} & Water crisis \\
\hline & Increased water salinity \\
\hline & Deterioration of water nutrients \\
\hline & Irrigation water shortage \\
\hline & Damaged agro wells \\
\hline \multirow[t]{11}{*}{4} & Pest incidence \\
\hline & Pest out break \\
\hline & Arrival of new pests \\
\hline & Stem borer infestation \\
\hline & Leaf folder infestation \\
\hline & Rice mite infestation \\
\hline & Gall midge infestation \\
\hline & Thrips infestation \\
\hline & Plant hoppers infestation \\
\hline & Leaf hoppers infestation \\
\hline & Ear bug infestation \\
\hline \multirow[t]{10}{*}{5} & Disease menace \\
\hline & Disease out break \\
\hline & Occurrence of new diseases \\
\hline & Blast \\
\hline & Leaf spot \\
\hline & Bacterial blight \\
\hline & Sheath blight \\
\hline & Sheath rot \\
\hline & Rice tungro disease \\
\hline & False smut \\
\hline \multirow[t]{5}{*}{6} & Agro climatic status \\
\hline & Monsoon shifting \\
\hline & Reduction of no. of rainy days \\
\hline & Rise in temperature \\
\hline & Increased wind speed \\
\hline
\end{tabular}

\begin{tabular}{|c|c|}
\hline & Increased humidity \\
\hline & Severe drought \\
\hline \multirow[t]{5}{*}{7} & Economic fluctuations \\
\hline & Decreased crop yield \\
\hline & Increased input cost \\
\hline & Increased cost of cultivation \\
\hline & Decreased annual income from rice crop \\
\hline \multirow[t]{5}{*}{8} & Social situation \\
\hline & Migration \\
\hline & Increased organizational participation \\
\hline & Conflict \\
\hline & Better relations developed with extension workers \\
\hline \multirow[t]{5}{*}{9} & Health status \\
\hline & Vector borne diseases \\
\hline & Skin diseases \\
\hline & Respiratory diseases \\
\hline & Diarrheal diseases \\
\hline \multirow[t]{7}{*}{10} & Psychological grief \\
\hline & Anxiety \& worry \\
\hline & Mourning \\
\hline & Depression \\
\hline & Numbness \\
\hline & Apathy \\
\hline & Suicide attempt \\
\hline
\end{tabular}

After the finalization of major components, sub-components for each major component were identified, Thus, the ten major components and their subcomponents were selected to assess the perceived impact of climate change among the respondents.

\section{Procedure followed for index development}

\section{Perceived impact assessment index (PIAi)}

Perceived impact assessment index of climate change for respondents was obtained by adding the total scores of each indicator and its subdivision like Crop nature, Soil condition, Water crisis, Pest incidence, Disease menace, Agro climatic status, Economic fluctuations, Social situation, Health statusque, Psychological grief. It has been calculated by adopting the following mathematical formulae. The procedure had been followed with slight modifications as adopted by Ganesan [16], Ranganathan [17], Mansingh [18], Palmurugan [19] and Sakunthalai [20]. The scoring procedure on the operationalization are given below:

$P I A i=\frac{C N_{i}+S C_{i}+W C_{i}+P I i+D M i+A C S i+E F i+S S i+H S i+P G i}{10}$

Where,

PIAi - Perceived Impact Assessment index

CNi- Crop nature index

Sci - Soil condition index 
WCi - Water crisis index

PIi- Pest incidence index

DMi- Disease menace index

ACSi - Agro climatic status index

EFi- Economic fluctuation index

SSi- Social situation index

HSi- Health statusque index

PGi- Psychological grief index

\section{Crop nature index (CNi)}

Crop nature index is a measure of individual's perception on impact of climate change on respondents ie, changes in cropping system, harvesting time, crop growing season etc. The CNi was worked out by using the formula as given below

$C N i=\frac{C N i(A)}{C N i(A)}$

Where,

$\mathrm{CNi}=$ Crop nature index.

$\mathrm{CNi}(\mathrm{A})=$ Actual score obtained by an individual on crop nature.

CNi $(\mathrm{T})=$ Total maximum score for an individual on crop nature.

The same technique has been applied to assess every and each component (SCi, WCi, PIi, DMi, ACSi, EFi, SSi, His, PGi).

\section{Results}

\section{Analysis of perceived impact index}

Climate impact perceived responses for the identified ten indicators were obtained from respondents on three-point continuum. From the obtained scores, indicator-wise indexes were worked out. The results are presented in Table 4.

Table 4: Perceived impact of climate change among respondents.

\begin{tabular}{|c|c|c|}
\hline S.No. & Components & Index \\
\hline 1 & Crop nature & 0.702 \\
\hline 2 & Soil condition & 0.689 \\
\hline 3 & Water crisis & 0.706 \\
\hline 4 & Pest incidence & 0.646 \\
\hline 5 & Disease menace & 0.625 \\
\hline 6 & Agro climatic status & 0.755 \\
\hline 7 & Economic fluctuations & 0.92 \\
\hline 8 & Social situation & 0.597 \\
\hline 9 & Health statusque & 0.467 \\
\hline 10 & Psychological grief & 0.614 \\
\hline & Composite Perceived impact assessment & $\mathbf{0 . 6 7 2}$ \\
\hline
\end{tabular}

From the above table 4 , it could be seen that the composite perceived impact index on climate change worked out was 0.672 . The index range for various subcomponents, crop nature (0.702), soil condition (0.689), water crisis (0.706), pest incidence (0.646), disease menace (0.625), agro climatic status (0.755), economic fluctuations (0.920), social situation (0.597), health statusque (0.467) and psychological grief (0.614).

To comprehend, economic fluctuations, crop nature, soil condition, water crisis, agro climatic status were in higher index value than the composite perceived impact index. Hence it is clear that economic fluctuations were highly perceived by the respondents when compare with all other impacts of climate change. Further it could be understood that climate change impact on crop nature, soil, water, agro climate status were also perceived by the respondents.

\section{Crop nature}

Climate change is clearly recognized as a major threat to agricultural systems. The expected increase in temperature, atmospheric $\mathrm{CO}_{2}$, heavy and unseasonal rains, increased humidity, and drought are likely to affect crops. The findings with respect to perceived impact of climate change on crop nature are mentioned in Table 5.

Table 5: Perceived impact of climate change on different subcomponents of crop nature.

\begin{tabular}{|c|c|c|}
\hline S.No. & Crop Nature & Mean Scores \\
\hline 1 & Changes in cropping system & 1.84 \\
\hline 2 & Changes in harvesting time & 1.735 \\
\hline 3 & Changes in crop growing season & 2.116 \\
\hline 4 & Crop destruction & 2.175 \\
\hline & Average mean score & $\mathbf{1 . 9 6 6}$ \\
\hline
\end{tabular}

It is inferred from Table 5 that the average mean score worked out for the impact of climate change on crop nature was 1.966, where the sub items, crop destruction and changes in cropping growing season as identified with higher mean score of 2.175 and 2.116 respectively. The other sub item's mean scores fell below the average mean score.

Climate change is perceived as a serious threat to crops eco systems. Study area is situated near to the Cauvery river basin and is extremely vulnerable to the vagaries of weather. Due to erratic rainfall in quantity and distribution, and the area is often subjected to drought which results in crop destruction. Monsoon failure and shifting of monsoon may adversely affect the crop growing season.

\section{Soil condition}

The findings pertinent to the perceived impact of climate change on soil have been presented in Table 6 .

The data presented in Table 6 reveals that the average mean score worked out for the impact of climate change on soil 
condition was 1.939, whereas the sub items, reduced soil nutrient content and increased soil salinity secured higher mean score of 2.145 and 2.105 respectively. The other sub item's mean scores had fallen below the average mean score.

Table 6: Perceived impact of climate change on different subcomponents of soil condition.

\begin{tabular}{|c|c|c|}
\hline S.No. & Soil Condition & Mean Scores \\
\hline 1 & Decreased soil water holding capacity & 1.86 \\
\hline 2 & Increased soil salinity & 2.105 \\
\hline 3 & Reduced soil nutrient content & 2.145 \\
\hline 4 & Soil erosion & 1.79 \\
\hline 5 & Accumulation of trash and debris & 1.795 \\
\hline & Average mean score & $\mathbf{1 . 9 3 9}$ \\
\hline
\end{tabular}

It could be understood from the above result that most of the respondents perceived that reduced soil nutrient and increased soil salinity were the major impact due to climate change. Changing rainfall pattern might lead to the reduction of water in streams, rivers, water bodies and likely to result in high deposition of salt concentration in the water bodies. Increase in soil salinity might lead to decline vegetation cover. In turn, this may lead to decline in soil organic matter, which are generally dependent on inputs from above-ground vegetation. Soil salinity may also directly affect the soil biodegrades, leading to significant changes in soil properties, especially nutrient levels.

\section{Water crisis}

Respondents' perception on the consequential effect of climate change on water resources was measured and the results have been furnished in Table 7.

Table 7: Perceived impact of climate change on different subcomponents of water resources.

\begin{tabular}{|c|c|c|}
\hline S.No. & Water Crisis & Mean Scores \\
\hline 1 & Increased water salinity & 2.245 \\
\hline 2 & Deterioration of water nutrients & 2.145 \\
\hline 3 & Irrigation water shortage & 2.335 \\
\hline 4 & Damaged agro wells & 1.755 \\
\hline & Average mean score & $\mathbf{2 . 1 2}$ \\
\hline
\end{tabular}

It could be seen from Table 7 that irrigation water shortage (2.335), increased water salinity (2.245) and deterioration of water nutrients (2.245) were the major impact perceived by respondents. The average mean score of the impact of climate change on water condition was 2.120 .

Frequent rainfall with prolonged drought, variation in the temperature and less ground water potential leads to water scarcity. Greater salinity in irrigated water sources is one of the major problems that affect crop cultivation.

\section{Pest incidence}

Perceived impacts of climate change on pest problems like pest outbreak, arrival of new pest etc. were measured and the findings have been presented in Table 8.

Table 8: Perceived impact of climate change on different subcomponents of pest incidence.

\begin{tabular}{|c|c|c|}
\hline S.No. & Pest Incidence & Mean Scores \\
\hline 1 & Pest outbreak & 2.18 \\
\hline 2 & Arrival of new pests & 1.791 \\
\hline 3 & Stem borer infestation & 1.92 \\
\hline 4 & Leaf folder infestation & 1.801 \\
\hline 5 & Rice mite infestation & 1.552 \\
\hline 6 & Gall midge infestation & 1.772 \\
\hline 7 & Thrips infestation & 1.78 \\
\hline 8 & Plant hoppers infestation & 1.841 \\
\hline 9 & Leaf hoppers infestation & 1.8 \\
\hline 10 & Ear bug infestation & 1.75 \\
\hline & Average mean score & 1.818 \\
\hline
\end{tabular}

From Table 8, it could be observed that the average mean score of pest incidence was 1.818. Most of the respondents perceived that the pest outbreak (2.180), infestation of stem borer (1.920) and plant hoppers (1.841) have been intense due to climatic variation. Moreover, leaf folder infestation (1.801) and Leaf hoppers infestation (1.800) were also perceived by the respondents. Climate change influences the ecology and biology of insects. Increased temperature, moisture might adversely affect specific pest species and could result in proliferation of destructive pest population.

\section{Disease menace}

Table 9: Perceived impact of climate change on different subcomponents of disease menace.

\begin{tabular}{|c|c|c|}
\hline S.No. & Disease Menace & Mean Scores \\
\hline 1 & Disease outbreak & 2.201 \\
\hline 2 & Occurrence of new diseases & 1.75 \\
\hline 3 & Blast & 1.692 \\
\hline 4 & Leaf spot & 1.781 \\
\hline 5 & Bacterial blight & 1.732 \\
\hline 6 & Sheath blight & 1.8 \\
\hline 7 & Sheath rot & 1.68 \\
\hline 8 & Rice tungro disease & 1.79 \\
\hline 9 & False smut & 1.821 \\
\hline & Average mean score & $\mathbf{1 . 8 0 5}$ \\
\hline
\end{tabular}

Perceived impact of climate change on plant diseases like 
disease outbreak, occurrence of new diseases etc. were assessed and the results are shown in Table 9.

It is inferred from Table 9 that the average mean score of disease menace was 1.805. Disease outbreak (2.201), false smut (1.821) and infection of sheath blight (1.800) were the major impact of climatic variation perceived by respondents.

Rise in temperature affects the pollination in crop which results in poor grain setting. Fungal diseases are common and can spread via spores carried by wind. Dispersal plays a key role in the spread of crop disease. Crop diseases are often spread through an insect vector. Insect population could become more prolific and widespread variation occurs in temperature. If pests live longer and reproduce more, it could spread crop diseases into new production areas.

\section{Agro climatic status}

respondents' perceived impacts of climate change on agro climatic conditions were assessed and the results have been presented in Table 10.

Table 10: Perceived impact of climate change on different subcomponents of agro climatic status.

\begin{tabular}{|c|c|c|}
\hline S.No. & Agro Climatic Status & Mean Scores \\
\hline 1 & Monsoon shifting & 2.23 \\
\hline 2 & Reduction of No. of rainy days & 2.63 \\
\hline 3 & Rise in temperature & 2.305 \\
\hline 4 & Increased wind speed & 1.61 \\
\hline 5 & Increased humidity & 1.77 \\
\hline 6 & Severe drought & 2.65 \\
\hline & Average mean score & $\mathbf{2 . 1 9 9}$ \\
\hline
\end{tabular}

From Table 10, it could be observed that the average mean score of agro climatic status was 2.199. Severe drought (2.650), reduction of No. of rainy days (2.630) and rise in temperature (2.305) were major impact perceived by respondents. Increased climate variability would increase the risk of droughts. Severe drought has led to the hardening of the land in the worst-affected provinces, which would increase the chances of rain or even light rain.

\section{Economic fluctuations}

Perceived impact of respondents on the extent to which the climate change affects the crop yield, income, cost of cultivation, input cost etc were worked out and the findings are presented in Table 11.

From Table 11, it could be observed that decreased crop yields (2.915) and decreased annual income from crop (2.870) were secured high mean score under the criteria of economic fluctuations. Severe drought and occurrence of uneven rainfall resulted in crop loss, increased soil and water salinity and deterioration of nutrient content reduced the crop yield which reduced annual income.
Table 11: Perceived impact of climate change on different subcomponents of economic fluctuations.

\begin{tabular}{|c|c|c|}
\hline S.No. & Economic Fluctuations & Mean Scores \\
\hline 1 & Decreased crop yields & 2.915 \\
\hline 2 & Increased agricultural input costs & 2.61 \\
\hline 3 & Increased cost of cultivation & 2.68 \\
\hline 4 & Decreased annual income from crop & 2.87 \\
\hline & Average mean score & $\mathbf{2 . 7 6 8}$ \\
\hline
\end{tabular}

\section{Social situation}

Climate change is an inevitable phenomenon which influences the social conditions of the respondents. Hence an attempt was made to study the perceived impact of climate change on social condition and the findings are presented in Table 12.

Table 12: Perceived impact of climate change on different subcomponents of social situation.

\begin{tabular}{|c|c|c|}
\hline S.No. & Social situation & Mean scores \\
\hline 1 & Migration & 1.77 \\
\hline 2 & Increased organizational participation & 2.06 \\
\hline 3 & Conflict & 1.15 \\
\hline 4 & $\begin{array}{c}\text { Better relations developed with exten- } \\
\text { sion workers }\end{array}$ & 2.185 \\
\hline & Average mean score & 1.791 \\
\hline
\end{tabular}

Table 12 reveals that the average mean score worked out for the criteria of social condition was 1.791, where the sub items, better relations was developed with extension workers and increased organizational participation secured higher mean score of 2.185 and 2.060 respectively. The other sub item's mean scores fell below the average mean score.

The people in vulnerable area seek technical guidance to understand the risky and complex nature of technologies with respect to climate change adaptation. Hence to cope with climatic change they developed better relations with extension workers and increase their organizational participation.

\section{Health statusque}

The findings pertinent to the perceived impact of climate change on health status have been presented in Table 13.

Table 13: Perceived impact of climate change on different subcomponents of health statuesque.

\begin{tabular}{|c|c|c|}
\hline S.No. & Health Statuesque & Mean Scores \\
\hline 1 & Vector borne diseases & 1.87 \\
\hline 2 & Skin diseases & 1.12 \\
\hline 3 & Respiratory diseases & 1.01 \\
\hline 4 & Diarrheal diseases & 1.615 \\
\hline & Average mean score & $\mathbf{1 . 4 0 4}$ \\
\hline
\end{tabular}

It is inferred from Table 13 that the average mean score worked out for the impact of climate change on human health was 
1.404. Vector borne diseases and diarrheal diseases were secured higher mean score of 1.870 and 1.615 respectively. Hence it could be understood that majority of the respondents perceived that the vector borne and diarrhoea diseases were spread among them at the time of natural calamities.

Climate change creates critical public health problem which makes many existing diseases and conditions worse, it may also introduce new pests and pathogens into new regions or communities. When the extreme climate change become more frequent and intense the water and food were subjected to contaminate which resulted in transmission of diarrheal diseases.

\section{Psychological grief}

Climate change is likely to have significant and negative effects on mental health and well-being, which will be felt most by vulnerable populations and those with pre-existing serious mental illness. An attempt was made to measure the perception of respondents on psychological impact of climate change and the results have been presented in Table 14.

Table 14: Perceived impact of climate change on different subcomponents of psychological grief.

\begin{tabular}{|c|c|c|}
\hline S.No. & Psychological Grief & Mean Scores \\
\hline 1 & Anxiety \& worry & 2.485 \\
\hline 2 & Mourning & 1.89 \\
\hline 3 & Depression & 2.585 \\
\hline 4 & Numbness & 1.85 \\
\hline 5 & Apathy & 1.97 \\
\hline 6 & Suicide attempt & 1.035 \\
\hline & Average mean score & 1.969 \\
\hline
\end{tabular}

It is observed from the Table 14 the average mean score of the psychological impact of climate change was 1.969, where the sub item depression (2.585), anxiety and worry (2.485) were the major impact perceived by respondents due to climate change.

Extreme climatic events affect the crop growth which resulted in crop failure, yield reduction and reduced annual income of the farmers, which may create depression, anxiety and worry among them. Even in the absence of direct impacts, the perception and fear of climate change may threaten mental health.

\section{Conclusion}

As per perceived impact index analysis, crop destruction and decreased annual income from crop nature were experienced by majority of the respondents due to climate change. Hence, identification and popularization of alternative cropping system in the study area would help the affected farmers to cope with adverse climatic condition.

Reduced soil nutrient content was one of the major impacts perceived by respondents. Therefore, in order to improve the organic carbon content of the soil the importance of organic manures, vermiculture, biofertilizers, biopesticides has to be popularized for conserving soil fertility.

Most of the respondents perceived that pest and disease outbreaks were the severe problem due to climate change. Hence, an effort should be made by the scientists and extension agencies to evolve suitable pest and disease management system at the time of risky situation in the study area.

Drought monitoring system has to be established. Droughtrelated monitoring and reporting activities provide a baseline of information and provide a barometer of change in climatic conditions that may indicate the inception of drought. Strategic drought monitoring can be achieved by using drought indicators.

Most of the respondents reported that crop failure, yield reduction and reduced annual income creates depression, anxiety and worry among them. Hence, Counsellors, psychologists and other mental health providers help educate people about normal responses to extreme stress, they should work with individuals affected by disaster and trauma to find constructive ways of dealing with the emotional impact.

Therefore, issues related to environment, development, climate change and disasters risks have emerged out of the imbalance which are occurring due to unplanned human interventions. Environment has become more fragile and risks prone. Thus, the solutions must flow from an integrated framework and it is equally important that all the stakeholders-national and international must work together in respect of policy, legislation and programs on the ground so that the disturbed equilibrium of the climate is restored or otherwise the consequences would be much more disastrous.

Currently, there is little definitive research on what the impacts of climate change will be on different sectors of the Indian economy and people. A technically robust analysis is required to understand the feasibility and opportunities of low and continued high carbon growth paths and the effects of mitigation mechanisms. A more participatory debate involving political representatives, civil society actors and the bureaucracy, both at the national and sub-national level is needed to build a national consensus. The seriousness of climate change impacts, necessity, and options for adaptation and mitigation policies need to be discussed with all stakeholders. A better knowledge base and a more inclusive debate will allow India to take a more informed view on climate change both domestically and internationally and build broader support for implementing what are bound to be difficult options.

\section{References}

1. Krejcie RV, Morgan DW (1970) Determining sample size for research activities. Educational and Psychological Measurement 30(3): 607610. 
2. Asha Latha KV, Gopinath M (2011) The Impact of Climate Change on Karnataka's Agriculture by Spatial Techniques. Indian Journal of Agriculture and Economics 66(3): 405.

3. Gauraha AK (2011) Regional Climatic Change and Natural Resources Over Decades: A Perception Analysis. Indian Journal of Agriculture and Economics 66(3): 407.

4. Meena HE, Lugenja M, Stephenson M (2006) Climate Change Impacts on Livelihoods in Tanzania and Adaptation Options: Experience of Floods and Drought in Rufiji. The Centre for Energy, Environment, Science and Technology (Ceest Foundation) Netherlands Climate Change Assistance Programme (NCAP).

5. Sacramento A, Matavel A, Basilio M, Bila S (2009) Climate Change Impact and Coping Strategies in Chicualacuala District, Gaza Province, Mozambique. Joint Programme on Environmental Mainstreaming and Adaptation to Climate Change in Mozambique.

6. Gentle P, Maraseni NT (2012) Climate Change, Poverty and Livelihoods: Adaptation Practices by Rural Mountain Communities in Nepal. Environmental Science \& Policy 21: 24-34.

7. Chetan C (2007) Climate change may impact India's food security. Hindustan times, New Delhi, India.

8. Philip S (2010) Govt rings alarm bells on rising sea level off India coast.

9. Das N (2014) Sea level rise and inundation of coastal India.

10. UNFCCC (2007) Climate Change: Impacts, Vulnerabilities and Adaptation in Developing Countries, Germany.

11. Vandana S (2010) The Suicide Economy of Corporate Globalisation in Devkota Prabodh's. Impact of Climate Change in Indian Agriculture: A Major Threat for the survival of Indian Poor. Earth Concern Asia, April 2010 .
12. Roy J (2007) The Economics of Climate Change, A Review of Studies in the Context of South Asia with a Special Focus on India.

13. Ravindranath $\mathrm{NH}$, et al. (2013) Impact of Climate Change on Forests in India. Centre for Ecological Sciences, Indian Institute of Science, Bangalore, India.

14. Ravindranath NH, Sudha P (2004) Joint forest management in India: spread, performance and impacts, 2004, Universities Press, Hyderabad, India.

15. Martin Agerup, et al. (2004) Climate change and sustainable development: A Blueprint from The Sustainable Development Network. Hanway Print Centre: Great Britain.

16. Ganesan R (1989) Participation Pattern of Officials, Farm Leaders and Farmer Beneficiaries in Agricultural Development Schemes - A Critical Analysis, Unpub. Ph.D. Thesis, TNAU, Coimbatore, India.

17. Ranganathan G (1987) Consequences of innovational acceptance, R.1. Agricultural Extension 254, Dept. Project, Dept. of Agrl. Extension and Rural Sociology, TNAU, Coimbatore, India.

18. Paul MJ (1993) Construction and Standardization of Socio-economic Status Scale. Unpub. Ph.D. Thesis, TNAU, Coimbatore, India.

19. Palmurugan M (2002) Prospects of Empowering Farm Women in Irrigated Farming System. Unpub. M.Sc. (Ag.) Thesis, TNAU, Coimbatore, India.

20. Sakunthalai A (2004) Identification and Standardization of Critical Indicators to Measure Women Empowerment. Unpub. Ph.D., Thesis, TNAU, Coimbatore, India. 